\title{
MENINGKATKAN HASIL BELAJAR SISWA PADA MATA PELAJARAN IPS DENGAN MENGGUNAKAN MODEL PEMBELAJARAN SNOWBALL THROWING DI KELAS III SD NEGERI 104204 SAMBIREJO TIMUR
}

\author{
Rouli Barimbing \\ Surel: halimunimed@gmail.com
}

\begin{abstract}
ABSTRAK
Penelitian ini dilaksanakan di SD Negeri 104204 Sambirejo Timur. Adapun tujuan dari penelitian ini yaitu untuk meningkatkan hasil belajar siswa dengan menggunakan model pembelajaran kooperatif tipe Snowball Throwing pada materi pokok Jenis-Jenis Pekerjaan di kelas III SD Negeri 104204 Sambirejo Timur Tahun Ajaran 2016/2017. Subjek dalam penelitian ini adalah siswa kelas III SD Negeri 104204 Sambirejo Timur yang berjumlah 30 orang yang terdiri dari 17 siswa laki-laki dan 13 siswa perempuan. Hasil penelitian yang diperoleh dari 30 orang siswa pada tes awal (pre tes) diperoleh 7 siswa $(23,33 \%)$ yang mencapai syarat ketuntasan belajar dan 23 siswa $(76,66 \%)$ belum mencapai tingkat ketuntasan hasil belajar, dengan nilai rata-rata 49,87.
\end{abstract}

Kata Kunci: Hasil Belajar, Model Pembelajaran, Snowball Throwing

\section{PENDAHULUAN}

Mata pelajaran Ilmu

Pengetahuan Sosial diharapkan dapat mewujudkan proses pendidikan yang integral dan mampu mengembangkan kepribadian warga negara yang partisipatif bertanggung jawab yang akan menjadi landasan untuk perkembangan masyarakat Indonesia yang demokratis.

Dari hasil pengamatan di SD Negeri No.104204 Sambirejo Timur di Kecamatan Percut Sei Tuan dengan melakukan wawancara kepada guru kelas III dengan jumlah siswa yaitu 30 orang yang terdiri dari 17 orang siswa laki-laki dan 13 siswa perempuan, dimana nilai ulangan harian yang didapat yaitu rentang antara 4,0-6,5 yaitu sebanyak $75 \%$ siswa dikelas masih mendapat nilai dibawah $<70$, sedangkan $25 \%$ mendapat nilai rentang antara 6,5-8,0. Sedangkan nilai ketuntasan yang ingin dicapai 70 sehingga nilai ratarata siswa tidak mencapai nilai ketuntasan yang diharapkan.

Banyak faktor yang menyebabkan hasil belajar IPS siswa rendah yaitu faktor internal dan eksternal siswa. Faktor internal antara lain: motivasi belajar, intelegensi, kebiasaan dan rasa percaya diri. Sedangkan faktor eksternal adalah faktor yang terdapat dari luar siswa, seperti guru sebagai pengajar, strategi pembelajaran, sarana dan prasarana, dan lingkungan.

SD Negeri 060819 Kec. Medan Kota 
Dalam pembelajaran IPS, guru sering menggunakan metode pembelajaran ceramah yang bersifat konvensional yang mengakibatkan pembelajaran berpusat pada guru. Guru menjelaskan hanya sebatas materi yang harus diselesaikan dalam beberapa pertemuan karena mengejar target sesuai dengan kurikulum dan memberikan soal-soal latihan sehingga dapat membuat siswa jenuh. Metode pembelajaran ini tidak dapat membangkitkan semangat siswa dalam belajar. Hal ini tampak perilaku siswa yang cenderung hanya mendengar dan mencatat pelajaran yang diberikan guru.

Pembelajaran yang

disampaikan dalam pembelajaran IPS kurang menarik bagi siswa, hal ini dapat dilihat masih adanya siswa yang berbicara dengan teman sebangku pada saat guru menjelaskan materi pelajaran.

Dalam proses pembelajaran IPS banyak siswa yang tidak mau bertanya apalagi mengemukakan pendapat atau saran tentang materi yang diberikan, hanya sebagian saja yang aktif dan sebagian kurang mampu mengemukakan pendapat.

Dari masalah yang dikemukakan di atas, perlu dicari strategi dan model pembelajaran baru yang dapat melibatkan siswa secara aktif. Pembelajaran yang mengutamakan kompetensi yang berpusat pada siswa, memberikan pembelajaran dan pengalaman belajar yang relevan dalam kehidupan nyata. Di sinilah guru dituntut untuk merancang kegiatan pembelajaran yang mampu mengembangkan kompetensi, baik ranah kognitif, afektif maupun psikomotorik siswa. Model pembelajaran yang berpusat pada siswa dan penciptaan suasana yang menyenangkan sangat diperlukan untuk meningkatkan hasil belajar siswa dalam mata pelajaran IPS.

Berdasarkan uraian di atas maka peneliti merasa tertarik untuk mengadakan penelitian tindakan kelas dengan judul "Meningkatkan Hasil Belajar Siswa Pada Mata Pelajaran IPS Dengan Menggunakan Model Pembelajaran Snowball Throwing di Kelas IIIb SD Negeri 104204 Sambirejo Timur T.A 2016/2017"'

Tujuan penelitian yang akan dicapai dalam penelitian ini adalah Untuk meningkatkan hasil belajar siswa dengan menggunakan model pembelajaran Kooperatif tipe Snowball Throwing pada materi Globalisasi di kelas IIIb SD Negeri 104204 Sambirejo Timur T.A 2016/2017.

\section{METODE PENELITIAN}

Jenis penelitian ini adalah penelitian tindakan kelas (PTK). Dimana penelitian ini berupaya memaparkan penggunaan model pembelajaran Kooperatif tipe 
Snowball Throwing pada mata pelajaran IPS dalam meningkatkan hasil belajar siswa di kelas III SD Negeri 104204 Sambirejo Timur.

Variabel dalam penelitian ini adalah Hasil Belajar dan Model Pembelajaran Kooperatif tipe Snowball Throwing. Hasil belajar adalah kemampuan yang diperoleh siswa melalui proses belajar dimana pada dasarnya adalah hasil interaksi dan berbagai faktor yang mempengaruhi proses belajar secara keseluruhan.

Model pembelajaran
kooperatif tipe pembelajaran Snowball Throwing merupakan salah satu modifikasi dari teknik bertanya yang menitik beratkan pada kemampuan merumuskan pertanyaan yang dikemas dalam sebuah permainan yang menarik yaitu saling melemparkan bola salju (Snowball Throwing) yang berisi pertanyaan kepada sesama teman.

\section{HASIL DAN PEMBAHASAN}

Langkah awal sebelum
dilakukannya perencanaan dan tindakan terhadap siswa kelas IIIb SD Negeri 104204 Sambirejo Timur adalah pemberian tes awal (pretest) sebanyak 20 soal pilihan berganda kepada 30 siswa yang dilaksanakan pada tanggal 24 Februari 2017 tepatnya pada hari Kamis pukul 10.30 wib. Tes awal (pretest) bertujuan untuk mengetahui kemampuan awal siswa dalam memahami dan menyelesaikan soal yang berkaitan dengan Jenis-Jenis Pekerjaan.

Hasil belajar siswa pada tes awal (pre test) dapat dilihat pada gambar 1 di bawah ini:

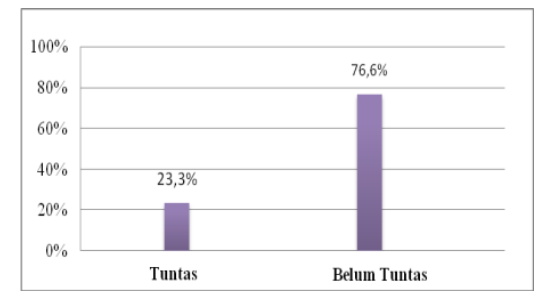

\section{Gambar 1. Hasil Belajar Siswa Pretes}

Dari gambar 1 di atas dapat dilihat bahwa dari 30 siswa terdapat 7 siswa $(23,33 \%)$ yang masuk kategori tuntas belajar dan 23 siswa $(76,66 \%)$ tidak tuntas belajar dengan nilai ratarata 49,83. Nilai tersebut berada dibawah nilai kriteria ketuntasan minimum (KKM) yaitu 70. Hal ini menunjukkan banyak siswa yang mengalami kesulitan dalam menyelesaikan soal yang berkaitan dengan Jenis-Jenis Pekerjaan. Dari ketuntasan klasikal yang diperoleh siswa, membuktikan bahwa hasil belajar siswa kelas III SD Negeri 104204 Sambirejo Timur masih rendah dan ketuntasan secara klasikal belum tercapai. Berdasarkan hasil perolehan nilai $\mathrm{di}$ atas peneliti melakukan perbaikan pembelajaran dengan melanjutkan pada tes siklus I, dan dalam pelaksanaan tindakan ini peneliti yang bertindak sebagai guru dengan menggunakan model 
pembelajaran kooperatif tipe Snowball Throwing diharapkan dapat meningkatkan hasil belajar siswa.

Dalam pelaksanaan tindakan siklus I ini yang menerapkan pembelajaran kooperatif tipe Snowball Throwing adalah peneliti, materi yang diajarkan yaitu JenisJenis Pekerjaan. Hasil belajar siklus I dapat dilihat pada gambar 2 di bawah ini:

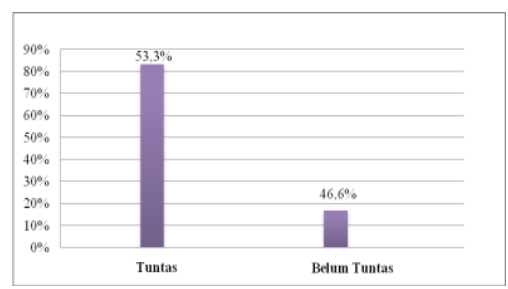

\section{Gambar. 2 Hasil Belajar Siswa} Siklus I

Dari gambar 2 di atas dapat dilihat hasil tes belajar pada siklus I terjadi peningkatan hasil belajar dengan nilai rata-rata 65,83. Dari 30 siswa yang mengikuti tes, terdapat $53,33 \%$ atau 16 siswa yang tuntas dalam pembelajaran dan $46,66 \%$ atau 14 siswa yang belum tuntas dalam pembelajaran.

Berdasarkan pengamatan guru kelas tampak bahwa kegiatan pelaksanaan yang dilakukan oleh peneliti cukup baik, akan tetapi masih ada beberapa kelemahan diantaranya guru belum mampu secara maksimal dalam mengelola kelas dan melaksanakan kegiatan belajar mengajar, efisiensi penggunaan waktu juga kurang. Untuk itu perlu dilakukan perbaikan agar pelaksanaan pembelajaran yang dilakukan oleh peneliti dan hasil belajar siswa lebih meningkat. Baik dalam mengorganisasikan siswa dalam kelompok belajar dan membimbing siswa dalam kelompok tersebut.

Pelaksanaan tindakan pada siklus II ini adalah melaksanakan kegiatan pembelajaran berdasarkan rencana pelaksanaan pembelajaran (RPP) dengan menggunakan model pembelajaran kooperatif tipe Snowball Throwing yang bertujuan untuk meningkatkan hasil belajar siswa. Hasil belajar siklus I dapat dilihat pada gambar 3 di bawah ini:

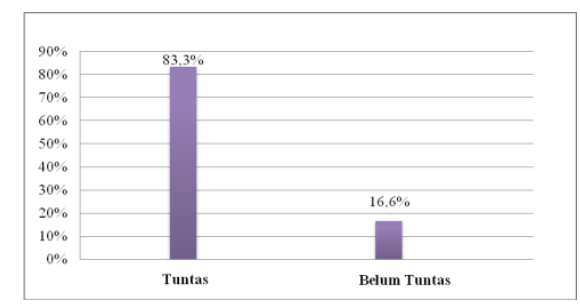

\section{Gambar 3. Hasil Belajar Siswa Siklus II}

Dari gambar 3 di atas dapat dilihat bahwa hasil belajar siswa pada siklus II mengalami peningkatan. Dilihat dari ketuntasan belajar secara klasikal telah mencapai $83,33 \%$ atau sebanyak 25 siswa dan 5 siswa belum tuntas $(16,66 \%)$. Dari hasil tersebut dapat disimpulkan kelas tersebut telah mencapai ketuntasan belajar yang diharapkan. 


\section{SIMPULAN}

Berdasarkan hasil pengamatan dan pengumpulan data penelitian yang dilakukan terhadap peningkatan hasil belajar siswa pada pembelajaran IPS pada materi pokok Jenis-Jenis Pekerjaan dengan menggunakan Model Pembelajaran Kooperatif Tipe Snowball Throwing di kelas III SD Negeri 104204 Sambirejo Timur, maka peneliti membuat kesimpulan sebagai berikut:

1. Penggunaan Model Pembelajaran Kooperatif Tipe Snowball Throwing dapat meningkatkan hasil belajar siswa pada materi pokok Jenis-Jenis Pekerjaan di kelas III SD Negeri 104204 Sambirejo Timur yang dapat dilihat dengan ketuntasan belajar siswa pada test awal sebanyak 7 $(23,33 \%)$ orang siswa yang tuntas dan $23(76,66 \%)$ orang siswa yang belum tuntas. Namun setelah dilakukan siklus I terjadi peningkatan ketuntasan belajar siswa sebesar $30 \%$ yaitu sebanyak $16(53,33 \%)$ siswa yang tuntas dan 14 ( 46,66\%) siswa yang belum tuntas. Dan pada siklus II ketuntasan belajar meningkat menjadi 25 ( $83,33 \%)$ siswa yang tuntas dan $5(16,66 \%)$ siswa yang belum tuntas.

2. Bahwa penggunaan Model Pembelajaran Kooperatif Tipe Snowball Throwing dapat meningkatkan hasil belajar siswa pada pelajaran IPS karena model pembelajaran tersebut dapat menjadikan siswa lebih aktif dan berpikir kritis.

\section{DAFTAR RUJUKAN}

Arikunto, Suharsimi. 2008. Penelitian Tindakan Kelas. Jakarta: Bumi Aksara.

Aqib, Zainal. 2010. Penelitian Tindakan Kelas. Bandung: Yarama Widya.

Fakultas Ilmu Pendidikan. 2011. Pedoman Penulisan Skripsi fakultas Ilmu Pendidikan. Medan: UnIIIersitas Negeri Medan.

Hamalik, Oemar. 2010. Proses Belajar Mengajar. Jakarta: Bumi Aksara.

Hamdani. 2011. Strategi Belajar Mengajar. Bandung: Pusataka Setia.

Isjoni. 2009. Pembelajaran Kooperatif. $\quad$ Yogyakarta: Pustaka Belajar.

Istarani. 2011. 58 Model Pembelajaran Inovatif. Medan: Media Persada.

Sagala, Syaiful. 2009. Konsep dan Makna Pembelajaran. Bandung: Alfabeta.

Slameto. 2010. Belajar dan FaktorFaktor Yang Mempengaruhinya. Jakarta: Rineka Cipta. 
Solihatin, Etin. 2017. Strategi Pembelajaran PIPS. Jakarta: Bumi Aksara.

Syah, Muhibbin. 2010. Psikologi Pendidikan. Bandung: Remaja Rosdakarya.

Syah, Muhibbin. 2011. Psikologi Pendidikan. Jakarta: Rajawali Pers.

Sudjana, Nana. 2009. Penilaian Hasil Proses Belajar Mengajar. Bandung: Remaja Rosdakarya.

Sumiati, Ati dan Bestari Prayoga. 2008. Pendidikan Kewarganegaraan 4. Jakarta: DEPDIKNAS.

Suprijono, Agus. 2009. Cooperative Learning dan Aplikasi PAIKEM. Yogyakarta: Pustaka Pelajar.

Trianto. 2009. Mendesain Model Pembelajaran InovatifProgresif. Jakarta: Kencana Prenada Media Group. 